\title{
Silicon as a Vegetable Crops Modulator-A Review
}

\author{
Prashant Kaushik ${ }^{1, *}$ and Dinesh Kumar Saini ${ }^{2}$ \\ 1 Instituto de Conservación y Mejora de la Agrodiversidad Valenciana, Universitat Politècnica de València, \\ 46022 Valencia, Spain \\ 2 Department of Plant Breeding and Genetics, Punjab Agricultural University, Ludhiana 141004, India; \\ dineshsaini-pbg@pau.edu \\ * Correspondence: prakau@doctor.upv.es; Tel.: +34-963-877000
}

Received: 18 April 2019; Accepted: 29 May 2019; Published: 31 May 2019

check for updates

\begin{abstract}
Vegetables require an optimum supply of mineral elements like silicon ( $\mathrm{Si}$ ). Si is second to oxygen in its abundance in the earth crust, and its role is quite significant in tackling biotic and abiotic stresses of vegetables. Si application also improves several agronomic and quality traits of vegetables. Hence, Si application is recommended as a strategy for the improvement of vegetable crops production. Although the research about the role of $\mathrm{Si}$ in vegetable dicots still lags far behind than cereals. Recently, omics-based approaches were used to provide a deeper understanding of the role of $\mathrm{Si}$ in vegetable protection. Here, we have compiled the studies focusing on the role of $\mathrm{Si}$ for vegetables, thus, enabling all of the important information regarding the effect $\mathrm{Si}$ application to vegetables at one place.
\end{abstract}

Keywords: vegetable; silicon; biotic; abiotic; stress

\section{Introduction}

Vegetables are vulnerable to a wide range of biotic and abiotic stresses; to overcome these stresses, vegetables requires an optimum supply of macro and micronutrients [1-3]. Silicon (Si) is crucial for plants; moreover, $\mathrm{Si}$ is always present in large quantities near the plant roots. [4]. Si occurs as silicates or silicon oxides, and around 27.7 percent of earth's crust is composed of $\mathrm{Si}$, but still, the available forms of $\mathrm{Si}$ meant for plants are scarce. Plants commonly use monosilicic acid $\left(\mathrm{H}_{4} \mathrm{SiO}_{4}\right)$ as the source of $\mathrm{Si}$ and $\mathrm{H}_{4} \mathrm{SiO}_{4}$ exists in the liquid form in soil. Moreover, the concentration of $\mathrm{H} 4 \mathrm{SiO} 4$ is not correlated to the total Si quantity of the soil. [5,6]. Regardless of the plentiful publications that establish Si application advantages in agriculture, $\mathrm{Si}$ is not regarded as an essential element. $\mathrm{Si}$ is classified as a quasi-essential element for plants [7]. Therefore, based on Si uptake, vegetables are divided into three groups, i.e., active, passive, and rejective. Whereas, based on the accumulation of $\mathrm{Si}$ in the cell wall apoplast, vegetables are classified as accumulators, excluders, and intermediate types [8,9]. The role of Si on plant health has been tested under open field conditions, hydroponic cultures, and under greenhouse/glasshouse environment [10]. Still, presently there are a limited number of studies which demonstrate there are advantages of $\mathrm{Si}$ application for greenhouse crops.

Meeting the growing demand for vegetables under situations of biotic and abiotic stresses is a big challenge. Si application is considered as an eco-friendly approach for crop production; therefore, $\mathrm{Si}$ application is commonly recommended under package and practices for cereals. Likewise, in vegetables, Si application has been documented to reduce the attack of diseases [11]. For example, potassium silicate treatment of pea seedlings was observed to increase chitinase and $\beta$-1,3-glucanase activity against the fungal pathogen Mycosphaerella pinodes and it is the causes of blight disease in pea [12]. Similarly, Si application has considerably reduced the root rot and powdery mildew disease in cucumber and the rust disease of cowpea [13-15]. Moreover, nano-silicon application can prevent 
postharvest diseases of vegetables [16,17]. In this direction, studies have also demonstrated that higher Si content in plant tissues reduced the incidence of several insect pests. [18]. Correa et al. [19] reported that soil or as a foliar spray of Si as calcium silicate to cucumber plants increases the mortality of the nymphs of Bemisia tabaci.

Correspondingly, several abiotic stresses affecting the vegetables are eradicated by the application of Si [20]. Si application was reported to alleviate high-temperature stress in vegetables [21]. Si application protects vegetables against the UV-B radiation by increasing photosynthesis and antioxidant levels [22]. Recently, omics-based approaches were applied to gain a genomic level perception of the mechanisms by which $\mathrm{Si}$ application aids vegetables in unfavorable circumstances. [23]. Heavy metals are detrimental for plant growth, and plants commonly accumulate heavy metals that are hazardous to human health. Si application is useful in reducing heavy metal toxicity. However, the role of $\mathrm{Si}$ for vegetables (dicots) is not well studied as compared to the model plants like Arabidopsis and rice. Subsequently, in many of the recent reviews on the role of Si in plants, the vegetable crops are underrepresented [24-26]. Therefore, we have structured our review focusing on the role of Si application for vegetables, especially, in tackling biotic and abiotic stresses, as well as the role of Si application on agronomic and quality traits of vegetables, thus, collating all of the important information regarding the effect of Si application to vegetables in one place.

\section{Biotic Stress}

\subsection{Fungal Pathogens}

\subsubsection{Cucurbitaceae}

The efficacy of Si application has been reported against many fungal pathogens. Using scanning electron microscopy, Samuels et al. [27] observed an overall negative correlation between the amount of $\mathrm{Si}$ and the growth of the causal agent of powdery mildew disease of cucumber (Sphaerotheca fuliginea). El-Samman [28] reported controlling the root rot of cucumber caused by Pythium aphanidermatum and Fusarium solani using the soluble formulation of Si. Foliar and root applied Si was determined to control the powdery mildew disease of cucumber [14]. Further, increased activities of plant protectants like superoxide dismutase (SOD), catalase (CAT), peroxidase (POD) in addition to the contents of ascorbate (AsA) and glutathione (GSH) were observed in the leaves of cucumber with Si application [29]. Si application was also effective against the oxidative stress induced by Phytophthora melonis infection in cucumber [30].

In 2006, Heine et al. [31] determined the ability of symplastic Si to reduce the spread of P. aphanidermatum in the roots of tomato and bitter gourd [32]. In 2010, Yu et al. [33] reported that Si application enhanced cucumber seedling growth and resistance level against Fusarium oxysporum f.sp. cucumerinum [34]. Si application as sodium silicate was found to be more effective against powdery mildew in melon as compared to nano-sized Si [35]. The effect of Si application on the severity and incidence of powdery mildew and quality traits like total soluble solids and dry matter contents have

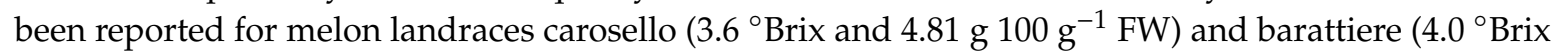

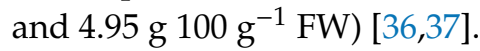

Increased activities of biochemical defense enzymes viz., peroxidase, polyphenol oxidase, and pathogenesis-related proteins (chitinase and $\beta$-1,3-glucanase) have been observed in bitter gourd with the application of soluble Si [38]. Guo et al. [39] used Si (silicon oxide and sodium silicate) for the control of postharvest pink rot (Trichothecium roseum) in Chinese cantaloupe. Si nutrient solution, have been tested for enhancing the tolerance to powdery mildew of hydroponically grown zucchini squash (Cucurbita pepo L.) [40]. The effectiveness of soil amendments for providing Si nutrition has been tested on pumpkin in contrast to the powdery mildew [41]. 


\subsubsection{Solanaceae}

In tomato, Diogo et al. [42] devised an alternative strategy for the management of fusarium crown and root rot (Fusarium oxysporum f.sp. radices lycopersici) using Si application to the tomato plant. [43]. Moreover, a positive effect of $\mathrm{Si}$ supplementation on post-harvest quality traits has been observed in tomato [44].

In capsicum and chilli pepper, the potential of Si application to decrease the symptoms of Phytophthora blight (Phytophthora capsici) development has also been confirmed [45]. Jayawardana et al. [46] reported Si induced resistance against anthracnose disease (Colletotrichum gloeosporioides) in chilli pepper.

\subsubsection{Leguminosae}

In soybean, absorption of $\mathrm{Si}$ in leaves of different soybean cultivars was quantified and correlated with the ability to enhance the resistance against soybean (Glycine max) rust (Phakopsora pachyrhizi) [47,48]. Similarly, a study indicated that the delay in disease onset was the possible cause of the final reduction in area under soybean rust progression curve [49].

\subsection{Bacterial Pathogens}

$\mathrm{Si}$ application is also effective against bacterial pathogens. For the first time, Dannon and Wydra [50] reported a significant effect of Si application against bacterial wilt disease of tomato (Ralstonia solanacearum). In this direction, Wydra et al. [51] found that $\mathrm{Si}$ accumulation mainly happened in the roots, and a negative correlation was reported between root Si content and bacterial growth. Ghareeb et al. [52] reported the up-regulated expression of the jasmonic acid/ethylene marker genes (JERF3, TSRF1, and ACCO) with Si application that induced resistance in tomato plants against R. solanacearum infestation [53]. With Si application, a significant boost in activities of enzymes viz., soil urease and soil acid phosphatase were reported under pathogen-inoculated conditions [54]. The resistance of tomato leaves to bacterial wilt mediated by Si application has been associated with the activation of defense-related enzymes such as peroxidase (POD) and phenylalanine ammonia lyase (PAL) [55].

\subsection{Insect Pest and Nematodes}

Studies have shown that $\mathrm{Si}$ application can increase the degree of resistance of host plants to insect pests. In this direction, the effect of Si application for resistance, against the whitefly (Bemisia tabaci) has been evaluated in tomato and cucumber $[19,56,57]$. Si application diminished the whitefly population on cucumber plants by reducing the insect oviposition, increasing growth cycle, and by causing high mortality at the nymph stages [19]. Whereas in soybean, Si application did not affect insect oviposition preferences but caused significant mortality at the nymph stages [56]. Recently, Callis-Duehl et al. [57] studied the role of $\mathrm{Si}$ application against $D$. balteata and B. tabaci of cucumber. Plant protection against insect pests with $\mathrm{Si}$ application is further correlated with the amount of increment of biochemical compounds like indols [58]. Recently, Dugui-Es et al. [59] demonstrated the effect of Si concentration and the frequency of application in managing the root-knot nematode, Meloidogyne incognita, in cucumber. The observed effects of Si application on biotic stresses faced by vegetables are presented in Table 1. 
Table 1. Summary of the effects of $\mathrm{Si}$ application against biotic stresses.

\begin{tabular}{|c|c|c|c|}
\hline Vegetable Crop & Form of Silicon Applied & Observed Effect of Silicon & Reference \\
\hline \multicolumn{4}{|l|}{ Fungal Pathogen } \\
\hline C. sativus & Silicate fertilizer & Promoted the growth and yield and also reduced the damage caused by wilt disease & [60] \\
\hline Cucumis sativus & Soluble silicates & Reduced the size of fungal colonies (S. fuliginea) & [27] \\
\hline C. sativus & Soluble silicon & Decreased the receptivity of plants to mildew infection caused by $S$. fuliginea & [61] \\
\hline C. sativus. and Solanum lycopersicon & Potassium silicate & Reduced the infection caused by Pythium and F.solani & [28] \\
\hline C. sativus & $\begin{array}{c}\text { Potassium silicate added to hydroponic } \\
\text { nutrient solutions }\end{array}$ & Suppressed powdery mildew (PM) caused by S.fuliginea & [62] \\
\hline C. sativus & Soluble silicon & Significantly decreased the powdery mildew disease (caused by S. fuliginea) index & [29] \\
\hline C. sativus & Potassium metasilicate & Significantly suppressed powdery mildew (P. xanthi) & [14] \\
\hline C. melo & Sodium silicate and nanosized silicon & Significantly decreased the severity of mildew powder & [35] \\
\hline S. lycopersicon and M. charantia & Silicic acid & $\begin{array}{l}\text { Symplastic Si was associated with the reduction of the spread of the fungus }(P . \\
\text { aphanidermatum) in roots }\end{array}$ & [31] \\
\hline C. sativus & & Significantly reduced the incidence of damping-off (P. aphanidermatum) & [32] \\
\hline C. melo & Sodium silicate & Reduced the postharvest rot (T. roseum) & [39] \\
\hline C. sativus & & Significantly decreased the disease index (S. fuliginea) & [63] \\
\hline C. melo & Potassium silicate & Reduced the severity and incidence of powdery mildew (S. fuliginea) & [36] \\
\hline C. реро & Potassium silicate & Enhanced the tolerance to salinity and resistance to powdery mildew (P. xanthii) & [40] \\
\hline C. sativus & Sodium silicate & Reduced downy mildew (P. cubensis) disease index & [33] \\
\hline C. аппиит & Calcium silicate & Potentially reduce the severity of Phytophthora blight & [45] \\
\hline C. sativus & Sodium silicate & Enhanced crop resistance to oxidative stress induced by $P$. melonis infection & [30] \\
\hline S. lycopersicon & Sodium metasilicate nonahydrate & $\begin{array}{l}\text { Reduced the disease severity of Fusarium crown and root rot (F. oxysporum f.sp. } \\
\text { radicis-lycopersici) }\end{array}$ & [43] \\
\hline G. $\max$ & Wollastonite & Controlled the soybean rust (P. pachyrhizi) & [49] \\
\hline C. melo & Potassium silicate & Controlled the powdery mildew (P. xanthi) & [37] \\
\hline C. sativus & Carbon Silpower solution & Inhibited powdery mildew (P. xanthi) development & [64] \\
\hline G. $\max$ & Potassium silicate & Protected plants against soybean rust (P. pachyrhizi) & [48] \\
\hline S. lycopersicon & Sodium silicate & Suppressed anthracnose disease (C. gloeosporiodes) & [44] \\
\hline S. lycopersicon & Potassium silicate & Reduced the severity and incidence of Fusarium wilt (F. oxysporum f. sp. lycopersici) & [65] \\
\hline S. lycopersicon & Potassium silicate & Reduced Fusarium wilt (F. oxysporum f. sp. lycopersici) & [66] \\
\hline
\end{tabular}


Table 1. Cont.

\begin{tabular}{|c|c|c|c|}
\hline Vegetable Crop & Form of Silicon Applied & Observed Effect of Silicon & Reference \\
\hline C. annuum & Potassium silicate & Enhanced resistance to anthracnose (Colletotrichum gloeosporioides) & [46] \\
\hline S. lycopersicon & Sodium silicate & $\begin{array}{l}\text { Controlled anthracanose disaese (C. gloeosporioides)and improved postharvest quality } \\
\text { of fruits }\end{array}$ & [67] \\
\hline M. charantia & Potassium silicate & Strengthened resistance in plants against powdery mildew (Erysiphe sp.) & [38] \\
\hline C. pepo & $\begin{array}{l}\text { Calcium silicate, } \mathrm{CaMg} \text { silicate slag, } \\
\text { wollastonite and MontanaGrowTM }\end{array}$ & Suppressed Powdery mildew (P. xanthii) & [41] \\
\hline S. lycopersicon & Silicon rich rice hull & Enhanced anthracnose resistance (C. dematium) & [68] \\
\hline C. sativus & Sodium silicate & $\begin{array}{l}\text { Enhanced resistance to Fusarium wilt (F. oxysporum f. sp. cucumerinum Owen) and } \\
\text { altered soil microbial communities }\end{array}$ & [34] \\
\hline \multicolumn{4}{|l|}{ Bacterial pathogen } \\
\hline S. lycopersicon & Monosilicic acid & Acted as an inducer of resistance against $R$. solanacearum & [50] \\
\hline S. lycopersicon & & Significantly reduced the incidence of bacterial wilt (R. solanacearum) & [51] \\
\hline S. lycopersicon & Soluble silicon & Reduced wilt incidence ( $R$. solanacearum) & [53] \\
\hline S. lycopersicon & Monosilicic acid and aerosol powder & Induced basal resistance against $R$. solanacearum & [42] \\
\hline S. lycopersicon & & Reduced severity and incidence of bacterial wilt (R. solanacearum) & [69] \\
\hline S. lycopersicon & Monosilicic acid & Induced resistance against $R$. solanacearum & [52] \\
\hline S. lycopersicon & Monosilicilic acid & Induced resistance against bacterial wilt (R. solanacearum) & [70] \\
\hline S. lycopersicon & Supa Sílica and calcium silicate & Reduced the symptoms of bacterial speck ( P. syringae pv. Tomato) & [71] \\
\hline S. lycopersicon & Potassium silicate & $\begin{array}{l}\text { Controlled R. solanacearum incidence by changing the soil microorganism amount and } \\
\text { enzyme activity }\end{array}$ & [54] \\
\hline Cucumis melo $\mathrm{L}$. & Calcium silicate & Induced resistance against bacterial fruit blotch (A. citrulli) & [72] \\
\hline S. lycopersicon & Monosilicic acid & Induced systemic resistance against bacterial wilt (R. solanacearum) & [73] \\
\hline S. lycopersicon & & Suppressed bacterial wilt (R. solanacearum) & [55] \\
\hline S. lycopersicon & Potassium silicate & Induced resistance against bacterial wilt (R. solanacearum) & [74] \\
\hline Cucumis melo L. & Calcium silicate & Enhanced resistance to bacterial fruit blotch (A. citrulli) & [75] \\
\hline \multicolumn{4}{|l|}{ Insect pest and nematodes } \\
\hline C. sativus & Calcium silicate & Acted as resistance Inducers against the Whitefly (B. tabaci) & [19] \\
\hline G. $\max$ & Silicic acid & significantly decreased the Silverleaf whitefly populations & [56] \\
\hline S. lycopersicon & AgrosilícioTM & $\begin{array}{l}\text { Controlled leafminer (T. absoluta) owing to toxic and anti-feeding effect to the } \\
\text { larval stage }\end{array}$ & [58] \\
\hline C. sativus & Potassium silicate & Acted as an anti-herbivore defense & [57] \\
\hline C. sativus & sodium metasilicate & Significantly reduced the activity of root-knot nematode (M. incognita) & [59] \\
\hline
\end{tabular}




\section{Abiotic Stresses}

\subsection{Salinity}

Salinity is a significant cause of yield losses in vegetables [76,77]. Salt stress results in the cations build-up that causes toxicity to the plant roots [78-81]. Salinity drastically affects the vegetables fresh and dry weight, photosynthetic rate, mesophyll conductance, and photosynthetic water use efficiency [82]. Several studies have reported the effect of Si application on salinity stress in vegetable crops (Table 1). Si mediated alleviation of salinity stress is associated with, a significant increase in the activities of antioxidants and decrease in the contents of electrolytic leakage percentage [83]. Likewise, the increase in activities of antioxidants like superoxide dismutase (SOD), catalase (CAT), was reported in spinach and bitter gourd under salinity $[84,85]$. The relationship between the amounts of antioxidants and plant growth under salinity stress has been studied for cucumber [86,87] and soybean [88].

Si application improved leaf turgor potential (42\%), net photosynthesis rates (20\%), water use efficiency (17\%) and the ratio between plant dry matter and plant water uptake (16\%) in tomato [89]. It has also been concluded that exogenous application of Si in combination with phyto-extracts of Melia azadirachta (Chinaberry) can effectively alleviate salinity-induced hazardous effects in pea [90]. Tantawy et al. [91] demonstrated that nano-Si is more effective and efficient in mitigating salinity stress in sweet pepper plants. Similarly, the use of nano- $\mathrm{SiO}_{2}$ has been reported in squash for activating the defense mechanisms of plants against salinity [92].

The mechanism of Si mediated salt tolerance is still not fully understood, and the possible role of $\mathrm{Si}$ in alleviating salt-induced osmotic stress with the underlying mechanism is still unexplored. Although, based on a study conducted on cucumber plants, it was suggested that Si application improved the salt tolerance by enhancing root water uptake, and also by up-regulating of aquaporin gene expression [93]. Si application during salinity stress prevented oxidative damage by increasing the activities of antioxidant enzymes and recovered the nutrient imbalance in C. annuum [94]. Si application increased the accumulation of polyamine in cucumber plants for salt tolerance [95].

\subsection{Drought}

Adequate regulation of plant nutrients may be helpful to maintain or even improve the plant water status thereby making the plant tolerant to drought stress. Si has been reported to confer tolerance to drought by regulating the leaf relative water content, transpiration, and stomatal conductance of plants [96,97]. Shen et al. [88] observed significant effects of Si application on photosynthesis and antioxidant parameters (viz., catalase, peroxidase) of soybean seedlings grown under drought stress. Si application mediated alleviation of drought stress on growth has been confirmed in soybean [98].

Likewise, application of exogenous Si improved seed germination and alleviated oxidative stress at the seedling stage of tomato [99] and by increasing the net photosynthetic rate in tomato leaves under water stress [100,101]. Shi et al. [102] suggested the role of Si-mediated decrease in membrane oxidative damage in increasing the root hydraulic conductance and water uptake hence improving water stress tolerance in tomato plants. Recently in 2017, Cao et al. [103] showed the role of changes in radial hydraulic conductivity and cell wall stability with $\mathrm{Si}$ application in tomato.

\subsection{Other stresses}

For osmotic stress studies, effects of Si on photosynthesis of young cucumber seedlings [104], and the activity of antioxidant enzymes in cucumber seedlings have been evaluated [105,106]. Whereas, for chilling stress, Liu et al. [107] showed that exogenous Si leads to greater deposition of endogenous Si and thereby increases antioxidants; and reduces the lipid peroxidation induced by chilling in cucumber. 


\subsection{Mineral Toxicity}

\subsubsection{Aluminum}

$\mathrm{Si}$ has been used in vegetable crops for alleviating the toxic effect of aluminum. For the first time in soybean, Baylis et al. [108] showed the alleviation of Al toxicity by Si. On these lines, Bityutskii et al. [109] highlighted the importance of both Fe and Si supply in exclusion of $\mathrm{Al}$ under acidic conditions from cucumber plants. Recently, Dorneles et al. [110] demonstrated that Si partially alleviated the damage caused by $\mathrm{Al}$ in the root growth parameters in potato via the elevated activity of antioxidant enzymes such as SOD and POD.

\subsubsection{Manganese}

In the case of manganese (Mn) toxicity, a study showed that Si supply alleviated Mn toxicity by the detoxification of apoplastic Mn [111]. In various studies, this alleviation of Mn toxicity by Si supply is related to the significant increase in the activities of antioxidants such as PPO, PODs, etc. [112-115]. In 2016, Dragišić Maksimović et al. [116] observed an enhanced cell wall stability owing to inert deposition of $\mathrm{Si}$ in the leaf cell walls of cucumber resulting in the decreased amount of toxic free Mn within the plant tissues.

\subsubsection{Cadmium}

The high amount of cadmium (Cd) is hazardous for vegetables, and $\mathrm{Si}$ has been used to ameliorate its effects in plants [117]. In cucumber, application of Si under cadmium stress protected the photosynthetic machinery from damages and improved the activities of nitrogen metabolism enzymes such as nitrogen reductase (NR) and glutamine synthetase (GS) [118]. Likewise, Wu et al. [119] also confirmed that Si application was reducing Cd uptake by roots in cucumber; whereas, in tomato, $\mathrm{Si}$ application was decreasing root-to-shoot $\mathrm{Cd}$ transport.

\subsubsection{Ammonium}

Excessive ammonium is associated with various physiological disorders in plants. Role of $\mathrm{Si}$ application has been investigated to minimize these disturbances in cucumber and tomato. Campos et al. [120] reported that the application of $\mathrm{Si}$, independent of the cucumber variety, mitigates the toxicity of ammonium and thereby enhances the dry matter of cucumber plants. Barreto et al. [121] recommended the use of $\mathrm{Si}$ in the nutrient solution $\left(\mathrm{Si}=1 \mathrm{mmolL}^{-1}\right)$ for the tomato plants grown under ammonium stress. The observed effects of $\mathrm{Si}$ application on abiotic stresses faced by vegetables are presented in Table 2 and Figure 1.

Table 2. Summary of the effects of Si application against abiotic stresses.

\begin{tabular}{|c|c|c|c|}
\hline Vegetable Crop & Form of Silicon Applied & Observed Effect of Silicon & Reference \\
\hline \multicolumn{4}{|l|}{ Salinity } \\
\hline C. sativus & Potassium silicate & $\begin{array}{l}\text { Alleviated salt stress and increased antioxidant } \\
\text { enzymes activity }\end{array}$ & [83] \\
\hline S. lycopersicon & Sodium silicate & Alleviated salt toxicity & [122] \\
\hline S. lycopersicon & Potassium silicate & Alleviated the deleterious salt effect & [89] \\
\hline C. sativus & Potassium silicate & Alleviated the salinity stress & {$[123,124]$} \\
\hline Spinacia oleracea & Sodium silicate & Increased stress tolerance & [84] \\
\hline C. sativus & & Enhanced salinity tolerance & [125] \\
\hline M. charantia & Potassium silicate & $\begin{array}{l}\text { Alleviated salt stress and increases antioxidant } \\
\text { enzymes activity }\end{array}$ & [85] \\
\hline G. $\max$ & Sodium metasilicate & Alleviated the detrimental effect of salinity stress & [126] \\
\hline C. sativus & Sodium silicate & Increased resistance against salinity & [127] \\
\hline
\end{tabular}


Table 2. Cont

\begin{tabular}{|c|c|c|c|}
\hline Vegetable Crop & Form of Silicon Applied & Observed Effect of Silicon & Reference \\
\hline Trigonella foenumgraceum & Sodium silicate & Increased the tolerance to salt stress & [128] \\
\hline S. lycopersicon & & Alleviated the effect of salinity stress & [129] \\
\hline S. lycopersicon & Silicon and nano silicon & Improved the salt tolerance & {$[82,130]$} \\
\hline C. sativus & Sodium silicate & Alleviated salt-oxidative stress & {$[86,93]$} \\
\hline Cucurbita pepo & nano-SiO2 & $\begin{array}{l}\text { Improved the defense mechanisms of plants against salt } \\
\text { stress toxicity }\end{array}$ & [92] \\
\hline C. sativus & Silicic acid & Enhanced the salt tolerance & [131] \\
\hline Pisum sativum & Potassium silicate & Alleviated the salinity-induced deleterious effects & [90] \\
\hline C. annumn & Nano Silicon & Improved salinity tolerance & [91] \\
\hline S. lycopersicon & Sodium silicate & Alleviated salinity stress & [132] \\
\hline C. satious & Sodium silicate & $\begin{array}{l}\text { Alleviated oxidative damage and improved plant growth } \\
\text { and photosynthetic performance }\end{array}$ & {$[95,133]$} \\
\hline C. annuum & Potassium silicate & Mitigated salinity stress & [94] \\
\hline S. lycopersicon & Nano-silicon & $\begin{array}{l}\text { Regulated the expression of salt tolerance genes under } \\
\text { salinity stress }\end{array}$ & [134] \\
\hline S. tuberosum & $\begin{array}{l}\text { Silicon dioxide } \\
\text { nanoparticles }\end{array}$ & Improved the salinity tolerance & [135] \\
\hline S. lycopersicon & Potassium silicate & Manipulated ion Distribution of plants under salt stress & [136] \\
\hline S. lycopersicon & Silicic acid & $\begin{array}{l}\text { Improved nutrient levels and yields under saline } \\
\text { conditions }\end{array}$ & [137] \\
\hline S. lycopersicon & Silicon nanoparticles & $\begin{array}{l}\text { Enhanced salinity tolerance and improved plant growth } \\
\text { with exopolysaccharide-producing bacteria }\end{array}$ & [138] \\
\hline \multicolumn{4}{|l|}{ Drought } \\
\hline Capsicum annuиm & & Increased the tolerance to water deficit & [96] \\
\hline C. annuum & Sodium metasilicate & Alleviated negative effects of water deficiency & [97] \\
\hline G. $\max$ & Sodium metasilicate & $\begin{array}{l}\text { Alleviated seedling damage under drought and } \\
\text { ultraviolet-B radiation }\end{array}$ & [88] \\
\hline G. $\max$ & Silicic acid & Mitigated the adverse effects of salt and drought stress & [98] \\
\hline S. lycopersicon & Sodium metasilicate & $\begin{array}{l}\text { Increased total chlorophylls under water-deficient } \\
\text { conditions }\end{array}$ & [139] \\
\hline S. lycopersicon & Silicic acid & $\begin{array}{l}\text { Improved seed germination and alleviated oxidative stress } \\
\text { under water deficit stress }\end{array}$ & [99] \\
\hline S. lycopersicon & Sodium silicate & $\begin{array}{l}\text { Restrained chlorophyll degradation and increased optimal } \\
\text { photosynthetic efficiency under drought stress }\end{array}$ & $\begin{array}{c}{[100,101,} \\
103]\end{array}$ \\
\hline S. lycopersicon & Potassium silicate & Enhanced the water stress tolerance & {$[102,140]$} \\
\hline \multicolumn{4}{|l|}{ Mineral toxicity } \\
\hline G. $\max$ & Soluble silicon & Alleviated the symptoms of Al toxicity & [108] \\
\hline Vigna unguiculata & Potassium silicate & Alleviated Mn toxicity & [111] \\
\hline C. sativus & Potassium silicate & Alleviated the Mn toxicity & [112] \\
\hline C. sativus & Silicic acid & $\begin{array}{l}\text { Alleviated Mn toxicity and modulated the metabolism and } \\
\text { utilization of phenolic compounds }\end{array}$ & [113] \\
\hline C. sativus & Sodium silicate & $\begin{array}{l}\text { Alleviated the adverse effects of excess Mn and cadmium } \\
\text { (Cd) toxicity }\end{array}$ & {$[114,118]$} \\
\hline C. sativus & & Improved antioxidant capacity of plant under $\mathrm{Cd}$ toxicity & [141] \\
\hline C. sativus & Silicic acid & $\begin{array}{l}\text { Ameliorated manganese toxicity by decreasing hydroxyl } \\
\text { radical accumulation }\end{array}$ & [115] \\
\hline S. lycopersicon & Calcium silicate & Mitigated the inhibitory effects of arsenic & [142] \\
\hline $\begin{array}{l}\text { S. lycopersicon and } \\
\text { C. sativus }\end{array}$ & $\begin{array}{l}\text { Sodium metasilicate } \\
\text { nonahydrate }\end{array}$ & Alleviated Cd stress & [119] \\
\hline C. satious & Sodium silicate & $\begin{array}{l}\text { Alleviated autotoxicity caused by 3-phenyl propionic acid } \\
\text { during seed germination }\end{array}$ & [87] \\
\hline C. sativus & Silicic acid & $\begin{array}{l}\text { Enhanced leaf remobilization of iron under limited iron } \\
\text { conditions }\end{array}$ & [116] \\
\hline
\end{tabular}


Table 2. Cont.

\begin{tabular}{cclc}
\hline Vegetable Crop & Form of Silicon Applied & \multicolumn{1}{c}{ Observed Effect of Silicon } & Reference \\
\hline C. sativus & Potassium silicate & Mitigated the toxicity of ammonium & {$[120]$} \\
\hline S. lycopersicon & Monosilicic acid & Mitigated ammonium toxicity & {$[121]$} \\
\hline C. sativus & Sodium silicate & Alleviated autotoxicity and Cd toxicity & {$[87]$} \\
\hline C. sativus & Silicic acid & Mitigated the Al toxicity under acidic conditions & {$[109]$} \\
\hline P. sativum & Orthosilicic acid & Alleviated Cd toxicity & {$[143]$} \\
\hline S. tuberosum & Sodium silicate & Improved the defense ability against Al toxicity & {$[110]$} \\
\hline Osmotic & & & Induced alleviation of growth reduction under osmotic \\
\hline C. sativus & & stress & {$[104]$} \\
\hline C. sativus & Silicon spray & $\begin{array}{l}\text { Enhanced the capacity of scavenging active oxygen species } \\
\text { and improved photosynthesis }\end{array}$ & {$[105]$} \\
\hline C. sativus & Sodium metasilicate & Contributed tolerance against osmotic stress & {$[106]$} \\
\hline S. lycopersicon & Monosilicic acid & $\begin{array}{l}\text { Regulated osmotic stress tolerance by differential } \\
\text { accumulation of relevant amino acids }\end{array}$ & {$[144]$} \\
\hline Cold & & & {$[107]$} \\
\hline C. sativus & Potassium silicate & Provided chilling tolerance & {$[22,88]$} \\
\hline UV-B & & & \\
\hline G. max & Sodium metasilicate & Enhanced nutrient acquisition under UV-B Radiation & \\
\hline
\end{tabular}

\begin{tabular}{|c|c|c|}
\hline 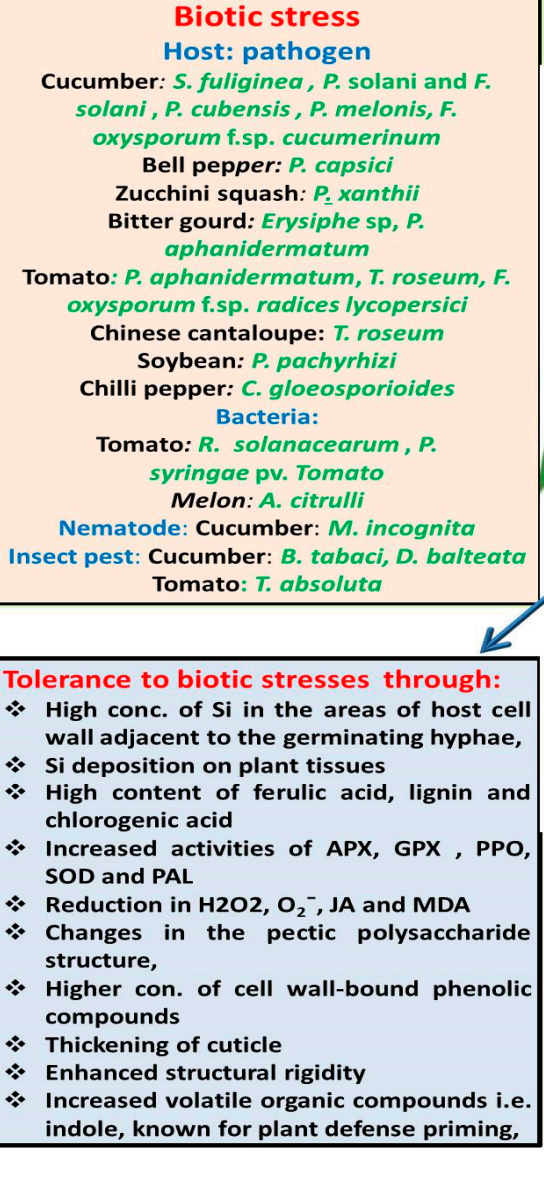 & & $\begin{array}{l}\text { Abiotic stress } \\
\text { Drought: Pepper, soybean and tomato } \\
\text { Salinity: Cucumber, tomato, spinach, bitter } \\
\text { gourd, fenugreek, squash, pea, sweet } \\
\text { pepper, potato } \\
\text { Chilling stress: cucumber } \\
\text { UV -B radiation: soybean } \\
\text { Osmotic stress: Cucumber, tomato } \\
\text { Nutrient toxicity } \\
\text { Aluminium:- soybean, cucumber, potato } \\
\text { (ii) Manganese:- cucumber, cowpea } \\
\text { (iii) Boron:- tomato } \\
\text { (iv) Cadmium:- cucumber, tomato, field pea } \\
\text { (v) Arsenic:- tomato } \\
\text { (vi) Ammonium:- cucumber, tomato } \\
\text { Nutrient deficiency } \\
\text { (i) Iron:- cucumber, soybean } \\
\text { (ii) Phosphorus:- potato }\end{array}$ \\
\hline
\end{tabular}

Figure 1. Schematic representation of various biotic and abiotic stresses overcome by Si application, along with the changes that take place after Si application. 


\section{Methods of Silicon Application on Vegetable Crops}

Various methods have been employed for applying the Si on plants such as Si solution, Si fertilizers, and foliar spray. The foliar spray could be an efficient method of application of $\mathrm{Si}$, but it has not been adequately tested. In this direction, an effort was made by Wolff et al. [64] who evaluated the efficiency of foliar applications of two commercially available Si-based products viz. Carbon Silpower®and Carbon Defense for their effect in reducing powdery mildew development in commercial greenhouse cucumber production. Results showed the starring role of foliar spray of Si for significantly reducing the severity and incidence of disease.

$\mathrm{Si}$ is commonly applied in the form of a solution. To our knowledge, for the first time Samuels et al. [27] raised cucumber plants in media supplemented with 100 ppm SiO2, (+Si) and studied the distribution pattern of $\mathrm{Si}$ in cucumber leaves during infection under powdery mildew fungus. Whereas foliar sprays with Si compounds are also applied. Further foliar sprays can be classified mainly into four categories, such as (a) foliar sprays with silicates viz. calcium silicate on melon [72], (b) foliar sprays with silicic acid viz. spray on soybean plants [56], (c) foliar sprays with other $\mathrm{Si}$ compounds, such as silica nanoparticles (nano-SiO2) on cucumber plants [1]; (d) foliar spray of commercially available Si-based products such as Carbon Silpower®and Carbon Defense® [64]. Nowadays, researchers are more focused on the use of nano form of $\mathrm{Si}$ for alleviating the effects of salt stress.

\section{Omics-Based Studies}

Some omics-based studies have been conducted in various vegetable crops to identify the differentially expressed genes to study the effect of $\mathrm{Si}$ application. For example, in the case of tomato, Kurabachew et al. [70] performed a transcriptome analysis in tomato plants treated with Si following inoculation with $R$. solanacearum and reported 174 differentially regulated genes (113 up-regulated and 61 down-regulated). Functional characterization of genes showed that most of the up-regulated genes were involved in defense. In another study, a transcriptomic survey of stress response-associated genes revealed that exposure of tomato plants to arsenic up-regulated glutathione reductase (LeGR). This inhibitory effect was mitigated by the addition of $\mathrm{Si}$ in the form of $\mathrm{CaSiO}_{3}$ [142]. In 2015, Zhu et al. [93] suggested that Si can improve salt tolerance of cucumber plants through up-regulation of the central plasma membrane aquaporin gene expression. Whereas, in the case of pea, recently in 2017, Rahman et al. [143] provided the mechanistic evidence on the beneficial effect of Si on Cd toxicity in pea plants, and transcriptome analysis revealed a predominant up-regulated expression of GSH1 (phytochelatin precursor) and MTA (metallothionein) transcripts in roots and down-regulated expression of pea Fe transporter (RIT1) in shoots.

In the case of proteomics, Chen et al. [74] explored the role of Si-mediated resistance to Ralstonia solanacearum in tomato root by a proteomics approach. They identified a total of 53 proteins. Forty-eight out of 53 proteins were significantly influenced by $\mathrm{Si}$ application. On these lines, a proteomics study in Capsicum annuum revealed that Si treatment up-regulated the accumulation of proteins involved in several metabolic processes, particularly those associated with transferase activity and nucleotide binding and modulated the expression of proteins involved in ubiquitin-mediated nucleosome pathway and carbohydrate metabolism [79]. In 2017, Bityutski et al. [109] highlighted the importance of both $\mathrm{Fe}$ and $\mathrm{Si}$ supply in plant exclusion of $\mathrm{Al}$ under acidic conditions; they reported that $\mathrm{Si}$ modulated the increase in root succinate and facilitated the long-distance transport of $\mathrm{Fe}$, thereby hindering $\mathrm{Al}$ transport from roots to shoots. Recently, Ali et al. [144] reported that Si is vital in regulating the metabolic content of tomato leaves under osmotic stress. They observed a change in the metabolite profile in roots (22) and leaves (27), respectively. 


\section{Silicon Transporters}

$\mathrm{Si}$ is absorbed by the plant roots in the form of silicic acid [145]. High Si accumulation in plants has been attributed to an efficient $\mathrm{Si}$ uptake system. However, to our knowledge, the molecular mechanism for Si uptake in vegetable crops is less understood and has only been reported in pumpkin [146,147], soybean [148], and cucumber [55,149]. For the first time in the dicotyledonous crop, an influx transporter of Si (CmLsi1: $C m L s i 1 \mathrm{~B}+$ and $C m L s i 1 \mathrm{~B}^{-}$) was identified in two pumpkin cultivars, significantly differing for $\mathrm{Si}$ accumulation. Si transporters, expressing in all root cells were localized plasma membrane and other at the endoplasmic reticulum (ER) [146]. Si uptake by plants is controlled by the actions of influx (Lsi1) and efflux (Lsi2) transporters. Deshmukh et al. [148] identified, characterized, and cloned two putative Si transporter genes, GmNIP2-1 and GmNIP2- 2 from soybean. Both genes, localized at the plasma membrane were expressed in shoot and root tissues. Two putative Si transporter genes (CSiT-1 and CSiT-2) have also been cloned and characterized in cucumber plants [131]. Recently, Sun et al. [149] isolated and characterized a gene CsLsi1, encoding a Si influx transporter in cucumber that shared around $55.70 \%$ and $90.63 \%$ homology with the Lsi1s of rice and pumpkin, respectively. This gene was localized at the plasma membrane for expression in roots.

\section{Conclusions}

$\mathrm{Si}$ is among the abundant elements on the earth. Here, we have discussed the role of $\mathrm{Si}$ application in protecting vegetable crops against several biotic and abiotic stresses. Although, $\mathrm{Si}$ absorption and availability to vegetables under natural conditions is low. The forms of Si commonly used for the plant application are potassium silicate, silica sol, slow-and NH4-silicates, etc. With the advancement in the omics-based approaches, information regarding the role of $\mathrm{Si}$, in shaping vegetable crops protection against abiotic and biotic stress is increasing. Further research regarding the uptake of Si by vegetables, to determine the newly available form of Si for plants, as well as the mechanisms behind Si application and plant stress elevation, has to be determined. This review focused on the role of silicon application for vegetables. For cereals, $\mathrm{Si}$ is on the verge of becoming a regular fertilizer, and we hope for an imitative trend in vegetables. The pathway of silicon, even in extensively cultivated vegetables remains to be explored. Hence, there is a need to employ omics-based approaches to identify in details the pathways and the genes responsible for the Si uptake by the vegetables to develop vegetable varieties with better Si uptake mechanisms.

Author Contributions: P.K. conceived of and designed the project. P.K. supervised the study. D.K.S. and P.K. wrote the paper. P.K. corrected the final draft. Both authors read and approved the final manuscript.

Funding: This research received no external funding.

Acknowledgments: The authors are thankful to the anonymous reviewers for their careful reading of the manuscript and providing insightful suggestions.

Conflicts of Interest: The authors declare no conflict of interest.

\section{References}

1. Ben Rejeb, I.; Pastor, V.; Mauch-Mani, B. Plant Responses to Simultaneous Biotic and Abiotic Stress: Molecular Mechanisms. Plants 2014, 3, 458-475. [CrossRef] [PubMed]

2. Baloch, Q.B.; Chachar, Q.I.; Tareen, M.N. Effect of foliar application of macro and micro nutrients on production of green chilies (Capsicum annuum L.). J. Agric. Tech. 2008, 4, 177-184.

3. Younis, A.; Riaz, A.; Sajid, M.; Mushtaq, N.; Ahsan, M.; Hameed, M.; Tariq, U.; Nadeem, M. Foliar application of macro-and micronutrients on the yield and quality of Rosa hybrida cvs. Cardinal and Whisky Mac. Afr. Biotech. 2013, 12, 702-708.

4. Deshmukh, R.K.; Ma, J.F.; Bélanger, R.R. Editorial: Role of Silicon in Plants. Front. Plant Sci. 2017, 8. [CrossRef] 
5. Carpinteri, A.; Manuello, A. Reply to "Comments on 'Geomechanical and Geochemical Evidence of Piezonuclear Fission Reactions in the Earth's Crust'by A. Carpinteri and A. Manuello" by U. Bardi and G. Comoretto. Strain 2013, 49, 548-551. [CrossRef]

6. Meena, V.D.; Dotaniya, M.L.; Coumar, V.; Rajendiran, S.; Ajay; Kundu, S.; Rao, A.S. A Case for Silicon Fertilization to Improve Crop Yields in Tropical Soils. Proc. Natl. Acad. Sci. India 2014, 84, 505-518. [CrossRef]

7. Epstein, E. Silicon. Ann Review Plant Biol. 1999, 50, 641-664. [CrossRef] [PubMed]

8. White, P.J.; Brown, P.H. Plant nutrition for sustainable development and global health. Ann. Bot. 2010, 105, 1073-1080. [CrossRef]

9. Tamai, K.; Ma, J.F. Characterization of silicon uptake by rice roots. New Phytologist. 2003, 158, 431-436. [CrossRef]

10. Luyckx, M.; Hausman, J.-F.; Lutts, S.; Guerriero, G. Silicon and Plants: Current Knowledge and Technological Perspectives. Front. Plant Sci. 2017, 8. [CrossRef] [PubMed]

11. Bakhat, H.F.; Bibi, N.; Zia, Z.; Abbas, S.; Hammad, H.M.; Fahad, S.; Ashraf, M.R.; Shah, G.M.; Rabbani, F.; Saeed, S. Silicon mitigates biotic stresses in crop plants: A review. Crop Prot. 2018, 104, 21-34. [CrossRef]

12. Dann, E.K.; Muir, S. Peas grown in media with elevated plant-available silicon levels have higher activities of chitinase and $\beta$-1, 3-glucanase, are less susceptible to a fungal leaf spot pathogen and accumulate more foliar silicon. Australas. Plant Pathol. 2002, 31, 9-13. [CrossRef]

13. Heath, M.C.; Stumpf, M.A. Ultrastructural observations of penetration sites of the cowpea rust fungus in untreated and silicon-depleted French bean cells. Physiol. Mol. Plant Pathol. 1986, 29, 27-39. [CrossRef]

14. Liang, Y.C.; Sun, W.C.; Si, J.; Römheld, V. Effects of foliar-and root-applied silicon on the enhancement of induced resistance to powdery mildew in Cucumis sativus. Plant Pathol. 2005, 54, 678-685. [CrossRef]

15. Chérif, M.; Asselin, A.; Bélanger, R.R. Defense responses induced by soluble silicon in cucumber roots infected by Pythium spp. Phytopathology 1994, 84, 236-242. [CrossRef]

16. Barman, K.; Sharma, S.; Siddiqui, M.W. Emerging Postharvest Treatment of Fruits and Vegetables; CRC Press: Boca Raton, FL, USA, 2018; ISBN 978-1-351-04629-9.

17. James, A.; Zikankuba, V. Postharvest management of fruits and vegetable: A potential for reducing poverty, hidden hunger and malnutrition in sub-Sahara Africa. Cogent Food Agric. 2017, 3, 1312052. [CrossRef]

18. Reynolds, O.L.; Keeping, M.G.; Meyer, J.H. Silicon-augmented resistance of plants to herbivorous insects: A review. Ann. Appl. Biol. 2009, 155, 171-186. [CrossRef]

19. Correa, R.S.; Moraes, J.C.; Auad, A.M.; Carvalho, G.A. Silicon and acibenzolar-S-methyl as resistance inducers in cucumber, against the whitefly Bemisia tabaci (Gennadius) (Hemiptera: Aleyrodidae) biotype B. Neotrop. Entomol. 2005, 34, 429-433. [CrossRef]

20. Cooke, J.; Leishman, M.R. Consistent alleviation of abiotic stress with silicon addition: A meta-analysis. Func. Ecol. 2016, 30, 1340-1357. [CrossRef]

21. Ashraf, M.; Afzal, M.; Ahmad, R.; Maqsood, M.A.; Shahzad, S.M.; Aziz, A.; Akhtar, N. Silicon management for mitigating abiotic stress effects in plants. Plant Stress 2010, 4, 104-114.

22. Shen, X.; Li, J.; Duan, L.; Li, Z.; Eneji, A.E. Nutrient acquisition by soybean treated with and without silicon under ultraviolet-B radiation. J. Plant Nut. 2009, 32, 1731-1743. [CrossRef]

23. Majeed Zargar, S.; Nazir, M.; Kumar Agrawal, G.; Kim, D.-W.; Rakwal, R. Silicon in plant tolerance against environmental stressors: Towards crop improvement using omics approaches. Current Proteom. 2010, 7, 135-143. [CrossRef]

24. Sivanesan, I.; Park, S.W. The role of silicon in plant tissue culture. Front. Plant Sci. 2014, 5, 571. [CrossRef]

25. Frew, A.; Weston, L.A.; Reynolds, O.L.; Gurr, G.M. The role of silicon in plant biology: A paradigm shift in research approach. Ann. Bot. 2018, 121, 1265-1273. [CrossRef]

26. Hall, A.D.; Morison, C.G.T. Armstrong Henry Edward On the function of silica in the nutrition of cereals-Part I. Proceed. Royal Soc. London. 1906, 77, 455-477. [CrossRef]

27. Samuels, A.L.; Glass, A.D.M.; Ehret, D.L.; Menzies, J.G. Distribution of silicon in cucumber leaves during infection by powdery mildew fungus (Sphaerotheca fuliginea). Canad. J. Bot. 1991, 69, 140-146. [CrossRef]

28. El-Samman, M.G. The role of soluble silicon in controlling some root rot diseases of cucumber and tomato. Ann. Agric. Sci. (Cairo) 2000, 4, 1411-1419.

29. Wei, G.; Zhu, Z.; Li, J.; Yao, Q. Effects of silicon supply and Sphaerotheca fuliginea inoculation on resistance of cucumber seedlings against powdery mildew. J. Appl. Ecol. 2004, 15, 2147-2151. 
30. Mohaghegh, P.; Khoshgoftarmanesh, A.H.; Shirvani, M.; Sharifnabi, B.; Nili, N. Effect of silicon nutrition on oxidative stress induced by Phytophthora melonis infection in cucumber. Plant Dis. 2011, 95, 455-460. [CrossRef]

31. Heine, G.; Tikum, G.; Horst, W.J. The effect of silicon on the infection by and spread of Pythium aphanidermatum in single roots of tomato and bitter gourd. J. Exp. Bot. 2006, 58, 569-577. [CrossRef]

32. Hasan, A.K.; Samir, S.H. Effect of copper and silicon nutrients and salicylic acid to induce systemic resistance for cucumber plants against Pythium aphanidermatum (Edson) Fitz. Arab J. Plant Prot. 2007, 25, 171-174.

33. Yu, Y.; Schjoerring, J.K.; Du, X. Effects of silicon on the activities of defense-related enzymes in cucumber inoculated with Pseudoperonospora cubensis. J. of Plant Nut. 2010, 34, 243-257. [CrossRef]

34. Zhou, X.; Shen, Y.; Fu, X.; Wu, F. Application of Sodium Silicate Enhances Cucumber Resistance to Fusarium Wilt and Alters Soil Microbial Communities. Front. Plant Sci. 2018, 9, 624. [CrossRef]

35. Yurong, G.; Hua, Z.; Derong, C. Inhibitory mechanisms of two silicon compounds on mildew powder of melon. Sci. Agric. Sin. 2005.

36. Buttaro, D.; Bonasia, A.; Minuto, A.; Serio, F.; Santamaria, P. Effect of silicon in the nutrient solution on the incidence of powdery mildew and quality traits in carosello and barattiere (Cucumis melo L.) grown in a soilless system. J. Hort. Sci. Biotech. 2009, 84, 300-304. [CrossRef]

37. Dallagnol, L.J.; Rodrigues, F.A.; Tanaka, F.A.O.; Amorim, L.; Camargo, L.E.A. Effect of potassium silicate on epidemic components of powdery mildew on melon. Plant Pathol. 2012, 61, 323-330. [CrossRef]

38. Ratnayake, R.; Daundasekera, W.A.M.; Ariyarathne, H.M.; Ganehenege, M.Y.U. Some biochemical defense responses enhanced by soluble silicon in bitter gourd-powdery mildew pathosystem. Austral. Plant Pathol. 2016, 45, 425-433. [CrossRef]

39. Guo, Y.; Liu, L.; Zhao, J.; Bi, Y. Use of silicon oxide and sodium silicate for controlling Trichothecium roseum postharvest rot in Chinese cantaloupe (Cucumis melo L.). Int. J. Food Sci. Tech. 2007, 42, 1012-1018. [CrossRef]

40. Savvas, D.; Giotis, D.; Chatzieustratiou, E.; Bakea, M.; Patakioutas, G. Silicon supply in soilless cultivations of zucchini alleviates stress induced by salinity and powdery mildew infections. Environ. Exp. Bot. 2009, 65, 11-17. [CrossRef]

41. Lepolu Torlon, J.; Heckman, J.; Simon, J.; Wyenandt, C. Silicon soil amendments for suppressing powdery mildew on pumpkin. Sustainability 2016, 8, 293. [CrossRef]

42. Diogo, R.V.; Wydra, K. Silicon-induced basal resistance in tomato against Ralstonia solanacearum is related to modification of pectic cell wall polysaccharide structure. Physiol. Mol. Plant Pathol. 2007, 70, 120-129. [CrossRef]

43. Huang, C.-H.; Roberts, P.D.; Datnoff, L.E. Silicon suppresses Fusarium crown and root rot of tomato. J. Phytopathol. 2011, 159, 546-554. [CrossRef]

44. David, D.; Weerahewa, H.L.D. Silicon Suppresses Anthracnose Diseases in Tomato (Lycopersicon esculentum) by Enhancing Disease Resistance; OUSL: Nugegoda, Sri Lanka, 2012.

45. French-Monar, R.D.; Rodrigues, F.A.; Korndörfer, G.H.; Datnoff, L.E. Silicon suppresses Phytophthora blight development on bell pepper. J. Phytopathol. 2010, 158, 554-560. [CrossRef]

46. Jayawardana, H.; Weerahewa, H.L.D.; Saparamadu, M. Enhanced resistance to anthracnose disease in chili pepper (Capsicum annuum L.) by amendment of the nutrient solution with silicon. J. Horticult. Sci. Biotech. 2015, 90, 557-562. [CrossRef]

47. Kaushik, P.; Dhaliwal, M.S.; Kumar, S. Usefulness of Three under Exploited Vegetable Legumes- A Review. Int. J. Curr. Microbiol. Appl. Sci. 2018, 7, 861-870. [CrossRef]

48. Arsenault-Labrecque, G.; Menzies, J.G.; Bélanger, R.R. Effect of silicon absorption on soybean resistance to Phakopsora pachyrhizi in different cultivars. Plant Dis. 2012, 96, 37-42. [CrossRef]

49. Lemes, E.M.; Mackowiak, C.L.; Blount, A.; Marois, J.J.; Wright, D.L.; Coelho, L.; Datnoff, L.E. Effects of silicon applications on soybean rust development under greenhouse and field conditions. Plant Dis. 2011, 95, 317-324. [CrossRef]

50. Dannon, E.A.; Wydra, K. Interaction between silicon amendment, bacterial wilt development and phenotype of Ralstonia solanacearum in tomato genotypes. Physiol. Mol. Plant Pathol. 2004, 64, 233-243. [CrossRef]

51. Wydra, K.; Diogo, R.; Dannon, E.; Semrau, J. Soil amendment with silicon and bacterial antagonists induce resistance against bacterial wilt caused by Ralstonia solanacearum in tomato. Tropentag 2005. 
52. Ghareeb, H.; Bozsó, Z.; Ott, P.G.; Repenning, C.; Stahl, F.; Wydra, K. Transcriptome of silicon-induced resistance against Ralstonia solanacearum in the silicon non-accumulator tomato implicates priming effect. Physiol. Mol. Plant Pathol. 2011, 75, 83-89. [CrossRef]

53. Wydra, K.; Semrau, J.; Dannon, E.; Diogo, R. Characterization of the interaction of antagonistic bacteria and of silicon ( $\mathrm{SiO} \sim 2$ ) with tomato infected with Ralstonia solanacearum. Mitteilungen-Biolosichen Bundesantalt Fur Land Und Forstwirtschaft 2006, 408, 112.

54. Wang, L.; Cai, K.; Chen, Y.; Wang, G. Silicon-mediated tomato resistance against Ralstonia solanacearum is associated with modification of soil microbial community structure and activity. Biol. Trace Element Res. 2013, 152, 275-283. [CrossRef]

55. Wang, L.; Chen, Y.; Cai, K.; Wang, G. Effects of exogenous silicon supply on the activity of antioxidant enzymes of tomato leaves infected by Ralstonia solanacearum. J. South China Agric. Univ. 2014, 35, 74-78.

56. Ferreira, R.S.; Moraes, J.C. Silicon influence on resistance induction against Bemisia tabaci biotype B (Genn.)(Hemiptera: Aleyrodidae) and on vegetative development in two soybean cultivars. Neotrop. Entomol. 2011, 40, 495-500. [CrossRef]

57. Callis-Duehl, K.L.; McAuslane, H.J.; Duehl, A.J.; Levey, D.J. The effects of silica fertilizer as an anti-herbivore defense in cucumber. J. Hortic. Res. 2017, 25, 89-98. [CrossRef]

58. Dos Santos, M.C.; Junqueira, M.R.; de Sá, V.M.; Zanúncio, J.C.; Serrão, J.E. Effect of silicon on the morphology of the midgut and mandible of tomato leafminer Tuta absoluta (Lepidoptera: Gelechiidae) larvae. Invert. Surv. J. 2015, 12, 158-165.

59. Dugui-Es, C.; Pedroche, N.; Villanueva, L.; Galeng, J.; De, D.W. Management of root knot nematode, Meloidogyne incognita in cucumber (Cucumis sativus) using silicon. Comm. Agric. Appl. Biol. Sci. 2010, 75, 497-505.

60. Miyake, Y.; Takahashi, E. Effect of silicon on the growth of cucumber plant in soil culture. Soil Sci. Plant Nut. 1983, 29, 463-471. [CrossRef]

61. Menzies, J.G.; Ehret, D.L.; Glass, A.D.M.; Helmer, T.; Koch, C.; Seywerd, F. Effects of soluble silicon on the parasitic fitness of Sphaerotheca fuliginea on Cucumis sativus. Phytopathology (USA) 1991. [CrossRef]

62. Schuerger, A.C.; Hammer, W. Suppression of powdery mildew on greenhouse-grown cucumber by addition of silicon to hydroponic nutrient solution is inhibited at high temperature. Plant Dis. 2003, 87, 177-185. [CrossRef]

63. Yao, Q.; Zhang, X.; Jiang, W.; Wei, G. Influences of silicon on phenylalanine metabolism in cucumber leaves and its relation to resistance to powdery mildew. J. Jilin Agric. Univ. 2009, 31, 16-21.

64. Wolff, S.A.; Karoliussen, I.; Rohloff, J.; Strimbeck, R. Foliar applications of silicon fertilisers inhibit powdery mildew development in greenhouse cucumber. J. Food Agric. Environ. 2012, 10, 355-359.

65. Chitarra, W.; Gilardi, G.; Cogliati, E.E.; Pugliese, M.; Gullino, M.L.; Garibaldi, A. Effects of silicon and concentration of nutrient solution on the control of Fusarium wilt of tomato. Protezione delle Colture 2013, 59-60.

66. Chitarra, W.; Cogliati, E.; Pugliese, M.; Gilardi, G.; Gullino, M.L.; Garibaldi, A. Effect of silicates and electrical conductivity on Fusarium wilt of tomato grown soilless. In Proceedings of the VIII International Symposium on Chemical and Non-Chemical Soil and Substrate Disinfestation 1044, Torino, Italy, 13-17 July 2014; pp. 53-55.

67. Weerahewa, H.L.D.; David, D. Effect of silicon and potassium on tomato anthracnose and on the postharvest quality of tomato fruit (Lycopersicon esculentum Mill.). J. Nat. Sci. Found. Sri Lanka 2015, 43, 273-280. [CrossRef]

68. Somapala, K.; Weerahewa, D.; Thrikawala, S. Silicon rich rice hull amended soil enhances anthracnose resistance in tomato. Proced. Food Sci. 2016, 6, 190-193. [CrossRef]

69. Kurabachew, H.; Wydra, K. Induction of defense related enzymes and gene expression after resistance induction by rhizobacteria and silicon against Ralstonia solanacearum in tomato (Solanum lycopersicum). In Proceedings of the Conference on International Research on Food Security, Natural Resource Management and Rural Development, Zurich, Switzerland, 14-16 September 2010.

70. Kurabachew, H.; Stahl, F.; Wydra, K. Global gene expression of rhizobacteria-silicon mediated induced systemic resistance in tomato (Solanum lycopersicum) against Ralstonia solanacearum. Physiol. Mol. Plant Pathol. 2013, 84, 44-52. [CrossRef] 
71. Andrade, C.C.L.; Resende, R.S.; Rodrigues, F.Á.; Ferraz, H.G.M.; Moreira, W.R.; Oliveira, J.R.; Mariano, R.L.R. Silicon reduces bacterial speck development on tomato leaves. Trop. Plant Pathol. 2013, 38, 436-442. [CrossRef]

72. Conceição, C.S.; Felix, K.C.S.; Mariano, R.L.; Medeiros, E.V.; Souza, E.B. Combined effect of yeast and silicon on the control of bacterial fruit blotch in melon. Sci. Hort. 2014, 174, 164-170. [CrossRef]

73. Kurabachew, H.; Wydra, K. Induction of systemic resistance and defense-related enzymes after elicitation of resistance by rhizobacteria and silicon application against Ralstonia solanacearum in tomato (Solanum lycopersicum). Crop Prot. 2014, 57, 1-7. [CrossRef]

74. Chen, Y.; Liu, M.; Wang, L.; Lin, W.; Fan, X.; Cai, K. Proteomic characterization of silicon-mediated resistance against Ralstonia solanacearum in tomato. Plant Soil 2015, 387, 425-440. [CrossRef]

75. Ferreira, H.A.; do Nascimento, C.W.A.; Datnoff, L.E.; de Sousa Nunes, G.H.; Preston, W.; de Souza, E.B.; de Mariano, R.L.R. Effects of silicon on resistance to bacterial fruit blotch and growth of melon. Crop Prot. 2015, 78, 277-283. [CrossRef]

76. Shahbaz, M.; Ashraf, M.; Al-Qurainy, F.; Harris, P.J.C. Salt tolerance in selected vegetable crops. Crit. Rev. Plant Sci. 2012, 31, 303-320. [CrossRef]

77. Shannon, M.C.; Grieve, C.M. Tolerance of vegetable crops to salinity. Sci. Hort. 1998, 78, 5-38. [CrossRef]

78. Munns, R. Genes and salt tolerance: Bringing them together. New phytologist 2005, 167, 645-663. [CrossRef]

79. Bae, D.; Yong, K.; Chun, S. Effect of salt $(\mathrm{NaCl})$ stress on germination and early seedling growth of four vegetables species. J. Cent. Eur. Agric. 2006, 7, 273-282.

80. Rizwan, M.; Ali, S.; Ibrahim, M.; Farid, M.; Adrees, M.; Bharwana, S.A.; Zia-ur-Rehman, M.; Qayyum, M.F.; Abbas, F. Mechanisms of silicon-mediated alleviation of drought and salt stress in plants: A review. Environ. Sci. Pollut. Res. 2015, 22, 15416-15431. [CrossRef]

81. Witzel, K.; Mock, H.P. A proteomic view of the cereal and vegetable crop response to salinity stress. In Agricultural Proteomics Volume 2; Springer: Cham, Switzerland, 2016; pp. 53-69.

82. Haghighi, M.; Pessarakli, M. Influence of silicon and nano-silicon on salinity tolerance of cherry tomatoes (Solanum lycopersicum L.) at early growth stage. Sci. Hort. 2013, 161, 111-117. [CrossRef]

83. Zhu, Z.; Wei, G.; Li, J.; Qian, Q.; Yu, J. Silicon alleviates salt stress and increases antioxidant enzymes activity in leaves of salt-stressed cucumber (Cucumis sativus L.). Plant Sci. 2004, 167, 527-533. [CrossRef]

84. Eraslan, F.; Inal, A.; Pilbeam, D.J.; Gunes, A. Interactive effects of salicylic acid and silicon on oxidative damage and antioxidant activity in spinach (Spinacia oleracea L. cv. Matador) grown under boron toxicity and salinity. Plant Growth Regul. 2008, 55, 207. [CrossRef]

85. Wang, X.; Ou-yang, C.; Fan, Z.; Gao, S.; Chen, F.; Tang, L. Effects of exogenous silicon on seed germination and antioxidant enzyme activities of Momordica charantia under salt stress. J. Animal Plant Sci. 2010, 6, 700-708.

86. Khoshgoftarmanesh, A.H.; Khodarahmi, S.; Haghighi, M. Effect of silicon nutrition on lipid peroxidation and antioxidant response of cucumber plants exposed to salinity stress. Arch. Agron. Soil Sci. 2014, 60, 639-653. [CrossRef]

87. Bu, R.; Xie, J.; Yu, J.; Liao, W.; Xiao, X.; Lv, J.; Wang, C.; Ye, J.; Calderón-Urrea, A. Autotoxicity in cucumber (Cucumis sativus L.) seedlings is alleviated by silicon through an increase in the activity of antioxidant enzymes and by mitigating lipid peroxidation. J. Plant Biol. 2016, 59, 247-259. [CrossRef]

88. Shen, X.; Li, X.; Li, Z.; Li, J.; Duan, L.; Eneji, A.E. Growth, physiological attributes and antioxidant enzyme activities in soybean seedlings treated with or without silicon under UV-B radiation stress. J. Agron. Crop Sci. 2010, 196, 431-439. [CrossRef]

89. Romero-Aranda, M.R.; Jurado, O.; Cuartero, J. Silicon alleviates the deleterious salt effect on tomato plant growth by improving plant water status. J. Plant Physiol. 2006, 163, 847-855. [CrossRef]

90. Shahid, M.A.; Balal, R.M.; Pervez, M.A.; Abbas, T.; Aqueel, M.A.; Javaid, M.M.; Garcia-Sanchez, F. Foliar spray of phyto-extracts supplemented with silicon: An efficacious strategy to alleviate the salinity-induced deleterious effects in pea (Pisum sativum L.). Turk. J. Bot. 2015, 39, 408-419. [CrossRef]

91. Tantawy, A.S.; Salama, Y.A.M.; El-Nemr, M.A.; Abdel-Mawgoud, A.M.R. Nano silicon application improves salinity tolerance of sweet pepper plants. Int. J. ChemTech Res. 2015, 8, 11-17.

92. Siddiqui, M.H.; Al-Whaibi, M.H.; Faisal, M.; Al Sahli, A.A. Nano-silicon dioxide mitigates the adverse effects of salt stress on Cucurbita pepo L. Env. Toxicol. Chem. 2014, 33, 2429-2437. [CrossRef] 
93. Zhu, Y.-X.; Xu, X.-B.; Hu, Y.-H.; Han, W.-H.; Yin, J.-L.; Li, H.-L.; Gong, H.-J. Silicon improves salt tolerance by increasing root water uptake in Cucumis sativus L. Plant Cell Rep. 2015, 34, 1629-1646. [CrossRef]

94. Manivannan, A.; Soundararajan, P.; Muneer, S.; Ko, C.H.; Jeong, B.R. Silicon mitigates salinity stress by regulating the physiology, antioxidant enzyme activities, and protein expression in Capsicum annuum 'Bugwang'. BioMed Res. Int. 2016. [CrossRef]

95. Yin, J.; Jia, J.; Lian, Z.; Hu, Y.; Guo, J.; Huo, H.; Zhu, Y.; Gong, H. Silicon enhances the salt tolerance of cucumber through increasing polyamine accumulation and decreasing oxidative damage. Ecotoxicol. Environ. Safety 2019, 169, 8-17. [CrossRef]

96. Lobato, A.K.S.; Coimbra, G.K.; Neto, M.A.M.; Costa, R.C.L.; Santos, F.; Oliveira, N.; Luz, L.M.; Barreto, A.G.T.; Pereira, B.W.F.; Alves, G.A.R. Protective action of silicon on water relations and photosynthetic pigments in pepper plants induced to water deficit. Res. J. Biol. Sci. 2009, 4, 617-623.

97. Lobato, A.K.S.; Luz, L.M.; Costa, R.C.L.; Santos Filho, B.G.; Meirelles, A.C.S.; Oliveira Neto, C.F.; Laughinghouse, I.V.; Neto, M.A.M.; Alves, G.A.R.; Lopes, M.J. Silicon exercises influence on nitrogen compounds in pepper subjected to water deficit. Res. J. Biol. Sci. 2009, 4, 1048-1055.

98. Hamayun, M.; Sohn, E.-Y.; Khan, S.A.; Shinwari, Z.K.; Khan, A.L.; Lee, I.-J. Silicon alleviates the adverse effects of salinity and drought stress on growth and endogenous plant growth hormones of soybean (Glycine max L.). Pak. J. Bot. 2010, 42, 1713-1722.

99. Shi, Y.; Zhang, Y.; Yao, H.; Wu, J.; Sun, H.; Gong, H. Silicon improves seed germination and alleviates oxidative stress of bud seedlings in tomato under water deficit stress. Plant Physiol. Biochem. 2014, 78, $27-36$. [CrossRef]

100. Cao, B.; Ma, Q.; Zhao, Q.; Wang, L.; Xu, K. Effects of silicon on absorbed light allocation, antioxidant enzymes and ultrastructure of chloroplasts in tomato leaves under simulated drought stress. Sci. Hort. 2015, 194, 53-62. [CrossRef]

101. Ullah, U.; Ashraf, M.; Shahzad, S.M.; Siddiqui, A.R.; Piracha, M.A.; Suleman, M. Growth behavior of tomato (Solanum lycopersicum L.) under drought stress in the presence of silicon and plant growth promoting rhizobacteria. Soil Environ. 2016, 35, 65-75.

102. Shi, Y.; Zhang, Y.; Han, W.; Feng, R.; Hu, Y.; Guo, J.; Gong, H. Silicon enhances water stress tolerance by improving root hydraulic conductance in Solanum lycopersicum L. Front. Plant Sci. 2016, 7, 196. [CrossRef]

103. Cao, B.-L.; Wang, L.; Gao, S.; Xia, J.; Xu, K. Silicon-mediated changes in radial hydraulic conductivity and cell wall stability are involved in silicon-induced drought resistance in tomato. Protoplasma 2017, 254, 2295-2304. [CrossRef]

104. Hattori, T.; Sonobe, K.; Inanaga, S.; An, P.; Morita, S. Effects of silicon on photosynthesis of young cucumber seedlings under osmotic stress. J. Plant Nut. 2008, 31, 1046-1058. [CrossRef]

105. Zhang, P.Y.; Gao, R.G.; Yang, F.J.; Wang, X.F.; Wei, M.; Shi, Q.H.; Li, Y. Effects of silicon on photosynthetic characteristics and activity of antioxidant enzymes in continuous-cropped cucumber seedlings. J. Appl. Ecol. 2014, 25, 1733-1738.

106. Jafari, S.R.; Arvin, S.M.J.; Kalantari, K.M. Response of cucumber (Cucumis sativus L.) seedlings to exogenous silicon and salicylic acid under osmotic stress. Acta Biologica Szegediensis 2015, 59, 25-33.

107. Liu, J.-J.; Lin, S.-H.; Xu, P.-L.; Wang, X.-J.; Bai, J.-G. Effects of exogenous silicon on the activities of antioxidant enzymes and lipid peroxidation in chilling-stressed cucumber leaves. Agric. Sci. China 2009, 8, 1075-1086. [CrossRef]

108. Baylis, A.D.; Gragopoulou, C.; Davidson, K.J.; Birchall, J.D. Effects of silicon on the toxicity of aluminum to soybean. Comm. Soil Sci. Plant Anal. 1994, 25, 537-546. [CrossRef]

109. Bityutskii, N.P.; Yakkonen, K.L.; Petrova, A.I.; Shavarda, A.L. Interactions between aluminum, iron and silicon in Cucumber sativus L. grown under acidic conditions. J. Plant Physiol. 2017, 218, 100-108. [CrossRef]

110. Dorneles, A.O.S.; Pereira, A.S.; Sasso, V.M.; Possebom, G.; Tarouco, C.P.; Schorr, M.R.W.; Rossato, L.; Ferreira, P.A.A.; Tabaldi, L.A. Aluminum stress tolerance in potato genotypes grown with silicon. Bragantia 2019. [CrossRef]

111. Iwasaki, K.; Maier, P.; Fecht, M.; Horst, W.J. Effects of silicon supply on apoplastic manganese concentrations in leaves and their relation to manganese tolerance in cowpea (Vigna unguiculata (L.) Walp.). Plant Soil 2002, 238, 281-288. [CrossRef] 
112. Shi, Q.; Bao, Z.; Zhu, Z.; He, Y.; Qian, Q.; Yu, J. Silicon-mediated alleviation of Mn toxicity in Cucumis sativus in relation to activities of superoxide dismutase and ascorbate peroxidase. Phytochemistry 2005, 66, 1551-1559. [CrossRef]

113. Dragišić Maksimović, J.; Bogdanović, J.; Maksimović, V.; Nikolic, M. Silicon modulates the metabolism and utilization of phenolic compounds in cucumber (Cucumis sativus L.) grown at excess manganese. J. Plant Nut. Soil Sci. 2007, 170, 739-744. [CrossRef]

114. Feng, J.-P.; Shi, Q.-H.; Wang, X.-F. Effects of exogenous silicon on photosynthetic capacity and antioxidant enzyme activities in chloroplast of cucumber seedlings under excess manganese. Agric. Sci. China 2009, 8 , 40-50. [CrossRef]

115. Dragišić Maksimović, J.; Mojović, M.; Maksimović, V.; Römheld, V.; Nikolic, M. Silicon ameliorates manganese toxicity in cucumber by decreasing hydroxyl radical accumulation in the leaf apoplast. J. Exp. Bot. 2012, 63, 2411-2420. [CrossRef]

116. Dragišić-Maksimović, J.; Mojović, M.; Maksimović, V. Silicon facilitates manganese phytoextraction by cucumber (Cucumis sativus L.). Zaštita materijala 2016, 57, 424-429. [CrossRef]

117. Farooq, M.A.; Detterbeck, A.; Clemens, S.; Dietz, K.J. Silicon-induced reversibility of cadmium toxicity in rice. J. Exp. Bo.t 2016, 67, 3573-3585. [CrossRef]

118. Feng, J.; Shi, Q.; Wang, X.; Wei, M.; Yang, F.; Xu, H. Silicon supplementation ameliorated the inhibition of photosynthesis and nitrate metabolism by cadmium (Cd) toxicity in Cucumis sativus L. Sci. Hort. 2010, 123, 521-530. [CrossRef]

119. Wu, J.; Guo, J.; Hu, Y.; Gong, H. Distinct physiological responses of tomato and cucumber plants in silicon-mediated alleviation of cadmium stress. Front. Plant Sci. 2015, 6, 453. [CrossRef]

120. Campos, C.N.S.; de Mello Prado, R.; Caione, G.; de Lima Neto, A.J.; Mingotte, F.L.C. Silicon and excess ammonium and nitrate in cucumber plants. Afr. J. Agric. Res. 2016, 11, $276-283$.

121. Barreto, R.F.; Prado, R.M.; Leal, A.J.F.; Troleis, M.J.B.; Junior, G.S.; Monteiro, C.C.; Santos, L.C.N.; Carvalho, R.F. Mitigation of ammonium toxicity by silicon in tomato depends on the ammonium concentration. Acta Agric. Scand. 2016, 66, 483-488. [CrossRef]

122. Al-aghabary, K.; Zhu, Z.; Shi, Q. Influence of silicon supply on chlorophyll content, chlorophyll fluorescence, and antioxidative enzyme activities in tomato plants under salt stress. J. Plant Nut. 2005, 27, 2101-2115. [CrossRef]

123. Qian, Q.Q.; Zai, W.S.; Zhu, Z.J.; Yu, J.Q. Effects of exogenous silicon on active oxygen scavenging systems in chloroplasts of cucumber (Cucumis sativus L.) seedlings under salt stress. J. Plant Physiol. Mol. Biol. 2006, 32, 107-112.

124. Qiongqiu, Q.; Wenshan, Z.; Yong, H. Protection of exogenous silicon and CoQ10 on mitochondria in cucumber (Cucumis sativus L.) roots under salt stress. Sci. Agric. Sinica 2006, 39, 1208-1214.

125. Sun, Y.; Luo, W.; Zhang, W.; Zhou, X. Effects of exogenous silicon on germination characteristics of cucumber seeds under NaHCO3 stress. In Proceedings of the 2010 International Conference on Challenges in Environmental Science and Computer Engineering (CESCE), Wuhan, China, 6-7 March 2010; IEEE: Piscataway, NJ, USA, 2010; Volume 1, pp. 471-474.

126. Lee, S.K.; Sohn, E.Y.; Hamayun, M.; Yoon, J.Y.; Lee, I.J. Effect of silicon on growth and salinity stress of soybean plant grown under hydroponic system. Agrofor. Syst. 2010, 80, 333-340. [CrossRef]

127. Amirossadat, Z.; Ghehsareh, A.M.; Mojiri, A. Impact of silicon on decreasing of salinity stress in greenhouse cucumber (Cucumis sativus L.) in soilless culture. J. Biol. Environ. Sci. 2012, 6, 171-174.

128. Arouiee, H.; Kafi, M.; Neamati, S.H. Effect of Silicon on Growth and Physiological Parameters in Fenugreek (Trigonella foenumgraceum L.) Under Salt Stress. Int. J. Agric. Crop Sci. 2012, 4, 1554-1558.

129. Haghighi, M.; Afifipour, Z.; Mozafarian, M. The alleviation effect of silicon on seed germination and seedling growth of tomato under salinity stress. Veget. Crops Res. Bull. 2012, 76, 119-126. [CrossRef]

130. Avcu, S.; Akhoundnejad, Y.; Dassgan, H.Y. Effects of selenium and silicon on salt-stressed tomato. TABAD Tarmm Bilimleri Araștırma Dergisi 2013, 6, 183-188.

131. Wang, H.-S.; Yu, C.; Fan, P.-P.; Bao, B.-F.; Li, T.; Zhu, Z.-J. Identification of two cucumber putative silicon transporter genes in Cucumis sativus. J. Plant Growth Regul. 2015, 34, 332-338. [CrossRef]

132. Li, H.; Zhu, Y.; Hu, Y.; Han, W.; Gong, H. Beneficial effects of silicon in alleviating salinity stress of tomato seedlings grown under sand culture. Acta Physiol. Plant. 2015, 37, 71. [CrossRef] 
133. Zhu, Y.; Guo, J.; Feng, R.; Jia, J.; Han, W.; Gong, H. The regulatory role of silicon on carbohydrate metabolism in Cucumis sativus L. under salt stress. Plant Soil 2016, 406, 231-249. [CrossRef]

134. Almutairi, Z.M. Effect of nano-silicon application on the expression of salt tolerance genes in germinating tomato ('Solanum lycopersicum'L.) seedlings under salt stress. Plant Omics 2016, 9, 106.

135. Salah, M.H.; Al-Zahrani, H.S.; Metwali, E.M. Improving the Salinity Tolerance in Potato (Solanum tuberosum) by Exogenous Application of Silicon Dioxide Nanoparticles. Int. J. Agric. Biol. 2017, 19.

136. Yunus, Q.; Zari, M. Effect of Exogenous Silicon on Ion Distribution of Tomato Plants Under Salt Stress. Commun. Soil Sci. Plant Anal. 2017, 48, 1843-1851. [CrossRef]

137. Korkmaz, A.; Karagöl, A.; Akınoğlu, G.; Korkmaz, H. The effects of silicon on nutrient levels and yields of tomatoes under saline stress in artificial medium culture. J. Plant Nut. 2018, 41, 123-135. [CrossRef]

138. Isfahani, F.M.; Tahmourespour, A.; Hoodaji, M.; Ataabadi, M.; Mohammadi, A. Influence of Exopolysaccharide-Producing Bacteria and $\mathrm{SiO} 2$ Nanoparticles on Proline Content and Antioxidant Enzyme Activities of Tomato Seedlings (Solanum lycopersicum L.) under Salinity Stress. Pol. J. Environ. Stud. 2018, 28, 153-163. [CrossRef]

139. Silva, O.N.; Lobato, A.K.S.; Avila, F.W.; Costa, R.C.L.; Oliveira Neto, C.F.; Santos Filho, B.G.; Martins Filho, A.P.; Lemos, R.P.; Pinho, J.M.; Medeiros, M. Silicon-induced increase in chlorophyll is modulated by the leaf water potential in two water-deficient tomato cultivars. Plant Soil Environ. 2012, 58, 481-486. [CrossRef]

140. Zhang, Y.; Yu, S.H.I.; Gong, H.; Zhao, H.; Li, H.; Hu, Y.; Wang, Y. Beneficial effects of silicon on photosynthesis of tomato seedlings under water stress. J. Integ. Agric. 2018, 17, 2151-2159. [CrossRef]

141. Khodarahmi, S.; Khoshgoftarmanesh, A.H.; Mobli, M. Effect of silicon nutrition on alleviating cadmium toxicity-induced damage on cucumber (Cucumis sativus L.) at vegetative stage. J. Sci. Tech. Greenhouse Cult. 2012, 3, 103-110.

142. Marmiroli, M.; Pigoni, V.; Savo-Sardaro, M.L.; Marmiroli, N. The effect of silicon on the uptake and translocation of arsenic in tomato (Solanum lycopersicum L.). Env. Exp. Bot. 2014, 99, 9-17. [CrossRef]

143. Rahman, M.F.; Ghosal, A.; Alam, M.F.; Kabir, A.H. Remediation of cadmium toxicity in field peas (Pisum sativum L.) through exogenous silicon. Ecotoxicol. Environ. Safety 2017, 135, 165-172. [CrossRef]

144. Ali, N.; Schwarzenberg, A.; Yvin, J.-C.; Hosseini, S.A. Regulatory Role of Silicon in Mediating Differential Stress Tolerance Responses in Two Contrasting Tomato Genotypes Under Osmotic Stress. Front. Plant Sci. 2018, 9, 1475. [CrossRef]

145. Mitani, N.; Ma, J.F. Uptake system of silicon in different plant species. J. Exp. Bot. 2005, 56, $1255-1261$. [CrossRef]

146. Mitani, N.; Yamaji, N.; Ago, Y.; Iwasaki, K.; Ma, J.F. Isolation and functional characterization of an influx silicon transporter in two pumpkin cultivars contrasting in silicon accumulation. Plant J. 2011, 66, 231-240. [CrossRef]

147. Mitani-Ueno, N.; Yamaji, N.; Ma, J.F. Silicon efflux transporters isolated from two pumpkin cultivars contrasting in Si uptake. Plant Signal. Behav. 2011, 6, 991-994. [CrossRef]

148. Deshmukh, R.K.; Vivancos, J.; Guérin, V.; Sonah, H.; Labbé, C.; Belzile, F.; Bélanger, R.R. Identification and functional characterization of silicon transporters in soybean using comparative genomics of major intrinsic proteins in Arabidopsis and rice. Plant Mol. Biol. 2013, 83, 303-315. [CrossRef]

149. Sun, H.; Guo, J.; Duan, Y.; Zhang, T.; Huo, H.; Gong, H. Isolation and functional characterization of CsLsi1, a silicon transporter gene in Cucumis sativus. Physiol. Plant. 2017, 159, 201-214. [CrossRef]

(C) 2019 by the authors. Licensee MDPI, Basel, Switzerland. This article is an open access article distributed under the terms and conditions of the Creative Commons Attribution (CC BY) license (http://creativecommons.org/licenses/by/4.0/). 